\title{
ĐÁNH GIÁ HIỂU QUẢ TÀI CHÍNH CỦA MộT SỐ Hệ THỐNG CANH TÁC CHỦ YẾU TRỂN ĐẤT NHIỄM MẬN TẠI HƯYỆN THẠNH PHÚ, TỈNH BẾN TRE VÀ HUYỆN U MINH THỰ̛̣NG, TỈNH KIÊN GIANG
}

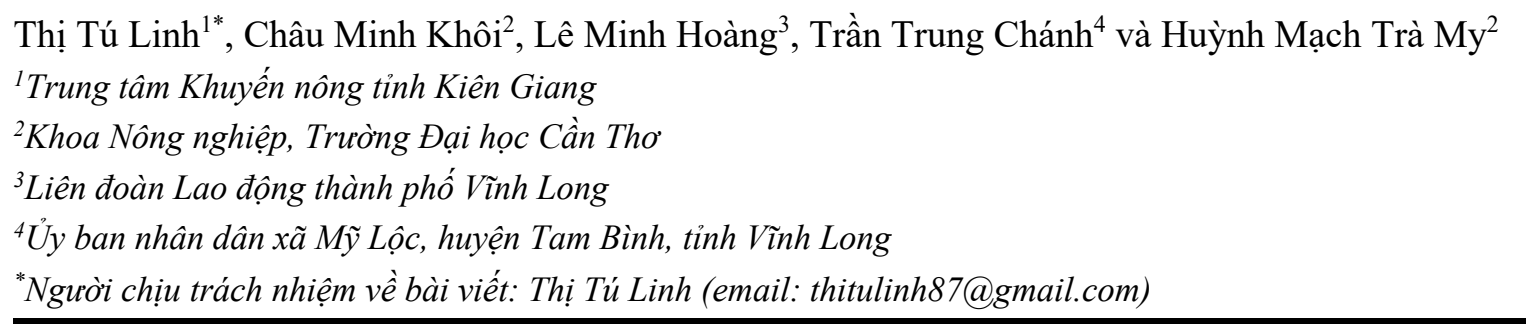

\section{Thông tin chung:}

Ngày nhận bài: 05/07/2021

Ngày nhận bài sưa: 03/11/2021

Ngày duyệt đăng: 25/12/2021

\section{Title:}

Assessing financial performance of major farming systems in salinity affected areas in Thanh Phu district, Ben Tre province and U Minh Thuong district, Kien Giang province

\section{Tù khóa:}

Hệ thống canh tác, hiệu quả tài chinh, luân canh, nông hộ, xâm nhập mặn

\section{Keywords:}

Crop rotation, cropping system, financial performance, household, saline water intrusion

\begin{abstract}
This study was conducted to evaluate the impact of saltwater intrusion on financial performance of some cropping systems on salinity affected soil in Thanh Phu district, Ben Tre province and U Minh Thuong district, Kien Giang province. Data were collected by household interviews and the Participatory Rural Appraisal approach. The study results showed that farming in the study areas is facing some problems due to the impact of seawater intrusion and salinity and acidity. Besides, the low level of education of farmers is also a big obstacle in production. In addition, the cropping systems and financial performance in the two districts were different. In Thanh Phu district, Ben Tre province, the mono-vegetable system generated the highest profit, followed by the only coconut and double rice crops per year was in the lowest profit. In U Minh Thuong district, Kien Giang province, the double rice crops in rotation with melon provided the highest profit, followed by the triple rice crops per year system; whereas the mono rice cropping system resulted in the lowest profit.
\end{abstract}

\section{TÓM TẮT}

Nghiên cứu được thực hiện nhằm muc tiêu đánh giá tác động của xâm nhập mặn đến hiệu quả tài chính của một số hệ thống cây trồng trên đất nhiềm mặn tại huyện Thạnh Phú, tỉnh Bến Tre và huyện U Minh Thuợng, tỉnh Kiên Giang. Số liệu được thu thập thông qua phỏng vấn nông hộ và đánh giá nông thôn có sự tham gia. Kết quả nghiên cúu cho thấy hiện trạng canh tác tại khu vực nghiên cứu còn nhiều khó khăn do tác động của xâm nhập mặn và phèn mặn. Bên cạnh đó, trình độ học vấn của nông hộ thấp cũng là trở ngại không nhỏ trong sản xuất. Ngoài ra, hệ thống canh tác và hiệu quả tài chính ở hai huyện khác nhau. Tại huyện Thạnh Phú, tỉnh Bến Tre hệ thống chuyên canh rau cho lợi nhuận cao nhất, kế đến là chuyên canh dùa và lúa 2 vụ/năm thấp nhất. Tại huyện U Minh Thurọng, tỉnh Kiên Giang, hệ thống lúa 2 vu luân canh dưa lê cho lợi nhuận cao nhất, kế đến là lúa 3 vụ/năm và thấp nhất là lúa 2 vụ/năm. 


\section{GIỚI THIỆU}

Đồng bằng sông Cửu Long (ĐBSCL) nằm ở hạ lưu của sông Cửu Long, là vựa lúa lớn nhất của Việt Nam, đóng góp hơn $50 \%$ sản lượng lúa và $30 \%$ giá trị sản xuất nông nghiệp (Thanh, 2016). Tuy nhiên, trong những năm gần đây xâm nhập mặn đã và đang ảnh hưởng đến năng suất, diện tích gieo trồng và thời gian xuống giống lúa ở các tỉnh ven biển của ĐBSCL. Cụ thể, năm 2016, tổng diện tích trồng lúa bị thiệt hại trực tiếp do xâm nhập mặn lên tới gần 140.000 ha, trong đó, Bến Tre thiệt hại trên 13.000 ha và Kiên Giang với trên 34.000 ha (Cục Trồng trọt, 2016).

Tại Bến Tre đầu năm 2020, nước mặn xâm nhập sâu vào nội địa, độ mặn 4\%o đã xuất hiện ở nhiều huyện cách cửa sông từ $50 \mathrm{~km}-68 \mathrm{~km}$, trong đó Thạnh Phú là huyện ven biển có chiều dài bờ biển $25 \mathrm{~km}$ và dễ bị nhiễm mặn hàng năm do ảnh hưởng của triều cường biển Đông. Trước tác động của nước biển dâng, mặn xâm nhập sâu còn là mối quan tâm của nhiều địa phương khác. Huyện U Minh Thượng, tỉnh Kiên Giang có điều kiện tự nhiên không tiếp giáp với biển nhưng hàng năm bị ảnh hưởng gián tiếp của thủy triều biển Tây dâng cao và xâm nhập mặn từ vùng ven sông Cái Lớn (Ủy ban nhân dân (UBND) huyện U Minh Thượng, 2015). Theo Phòng Nông nghiệp và Phát triển nông thôn huyện U Minh Thượng (2020), tác động của xâm nhập mặn cuối năm 2019 đầu năm 2020 không chỉ gây thiệt hại nghiêm trọng đến vụ lúa Đông Xuân mà còn kéo dài và gây hại cho 1.648 ha lúa Hè Thu.

Trong thời gian tới, nếu mức độ xâm nhập mặn kéo dài và gia tăng, lượng mưa hàng năm không đủ để rửa mặn trong đất thì diện tích đất canh tác lúa ở huyện Thạnh Phú, Bến Tre và huyện U Minh Thượng, Kiên Giang sẽ tiếp tục giảm và có $x u$ hướng chuyển đổi sang các đối tượng canh tác khác phù hợp hơn. Do đó, nghiên cứu được thực hiện nhằm đánh giá hiện trạng và phân tích hiệu quả tài chính của một số hệ thống cây trồng chủ lực trong vùng chuyên canh lúa bị ảnh hưởng của xâm nhập mặn; trên cơ sở đó hỗ trợ địa phương trong việc nghiên cứu biện pháp cải thiện chất lượng đất để duy trì diện tích canh tác lúa hiện có hoặc định hướng chuyển đổi sang các hệ thống canh tác khác thích ứng với xâm nhập mặn trong thời gian tới.

\section{PHƯƠNG PHÁP NGHIÊN CÚU}

\subsection{Thời gian và địa điểm nghiên cứu}

Nghiên cứu được thực hiện vào tháng 3 năm 2021, đây là thời điểm khu vực nghiên cứu đang bị ảnh hưởng của xâm nhập mặn. Nghiên cứu được thực hiện tại hai huyện hàng năm bị ảnh hưởng của xâm nhập mặn từ hai triều cường khác nhau, trong đó, huyện Thạnh Phú, tỉnh Bến Tre bị ảnh hưởng của triều cường từ biển Đông bắt đầu từ tháng 01 đến tháng 4 hàng năm, và huyện $U$ Minh Thượng, tỉnh Kiên Giang bị ảnh hưởng của triều cường biển Tây bắt đầu từ tháng 02 đến tháng 5 hàng năm (Hình 1).

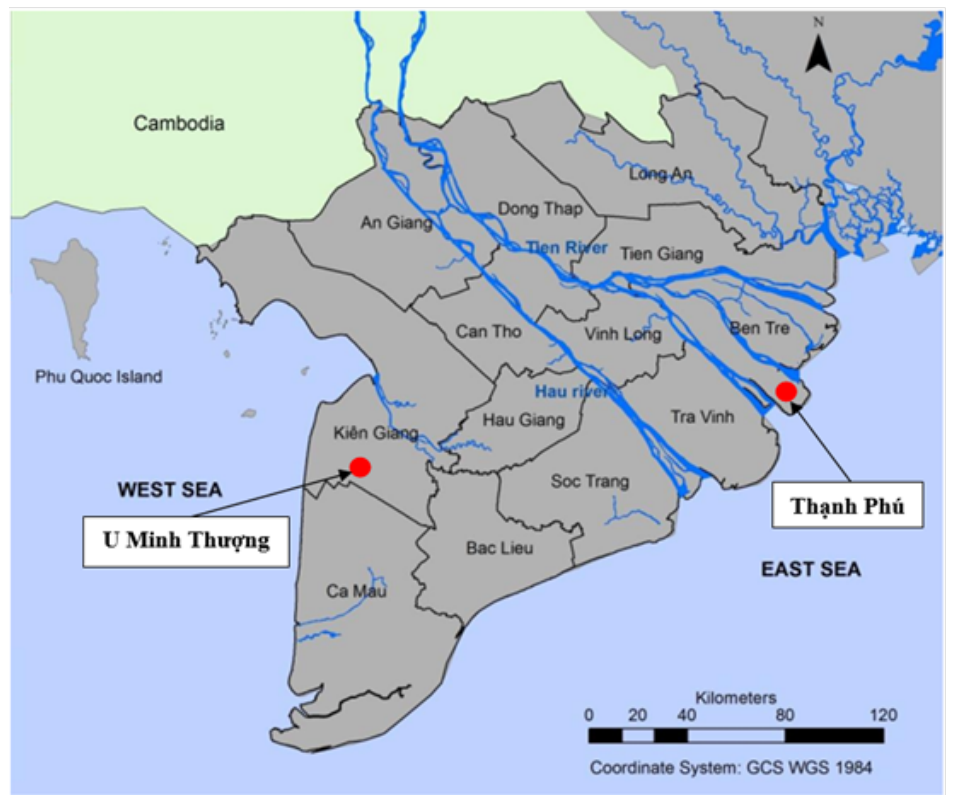

Hình 1. Bản đồ nghiên cứu tại huyện U Minh Thượng và huyện Thạnh Phú 


\subsection{Phương pháp thu thập số liệu}

\subsubsection{Chọn hệ thống canh tác và hộ khảo sát}

Việc lựa chọn hệ thống canh tác để nghiên cứu được thực hiện qua tham vấn cơ quan nông nghiệp huyện. Trên cơ sở đó, một số hệ thông canh tác được chọn lựa để nghiên cứu gồm các hệ thống cây trồng chuyên canh lúa, luân canh lúa - màu, chuyên canh rau màu, dừa. Đây là các hệ thống cây trồng được canh tác phổ biến ở khu vực nghiên cứu và bị ảnh hưởng của xâm nhập mặn (Bảng 1).

\section{Bảng 1. Phân bố mẫu khảo sát tại khu vực nghiên cứu}

\begin{tabular}{lrrr}
\hline Hệ thống canh tác & $\begin{array}{r}\text { Số mẫu tại huyện } \\
\text { Thạnh Phú }\end{array}$ & $\begin{array}{c}\text { Số mẫu tại huyện U Minh } \\
\text { Thượng }\end{array}$ & Tổng cộng \\
\hline Chuyên canh lúa 2 vụ & $\mathrm{N}=30$ & $\mathrm{~N}=30$ & $\mathbf{N}=\mathbf{6 0}$ \\
Chuyên canh lúa 3 vụ & & $\mathrm{N}=30$ & $\mathbf{N}=\mathbf{3 0}$ \\
Luân canh lúa - màu & $\mathrm{N}=20$ & $\mathrm{~N}=30$ & $\mathbf{N}=\mathbf{5 0}$ \\
Chuyên canh rau màu, dừa & $\mathrm{N}=40$ & & $\mathbf{N}=\mathbf{4 0}$ \\
\hline \multicolumn{1}{c}{ Tổng cộng } & 90 & 90 & 180 \\
\hline
\end{tabular}

Ghi chú: Các xã được chọn để khảo sát tại huyện Thạnh Phú gồm xã Hòa Lợi, xã Bình Thạnh, thị trấn Thạnh Phú, tại huyện U Minh Thương gồm xã Thạnh Yên, xã Minh Thuận, xã Vĩnh Hòa.

Thông tin chọn hộ khảo sát được Phòng Nông nghiệp và Phát triển nông thôn huyện Thạnh Phú và huyện U Minh Thượng cung cấp phù hợp với tiêu chí là hộ đang canh tác lúa 2 - 3 vụ/năm hoặc đã chuyển đổi từ diện tích canh tác lúa kém hiệu quả sang hệ thống cây trồng khác phù hợp hơn và có kinh nghiệm canh tác từ 5 năm trở lên.

\subsubsection{Thu thập số liệu thư cấp}

Số liệu thứ cấp được thu thập từ Cục thống kê tỉnh, các báo cáo của Ủy ban Nhân dân huyện, Phòng Nông nghiệp và Phát triển nông thôn huyện. Các loại số liệu thứ cấp thu thập bao gồm điều kiện sản xuất nông nghiệp, tình hình xâm nhập mặn, quy hoạch tổng thể phát triển kinh tế - xã hội, quy hoạch đất, quy hoạch ngành nông nghiệp, báo cáo thủy văn và các công trình nghiên cứu về sản xuất nông nghiệp tại huyện Thạnh Phú, tỉnh Bến Tre và huyện U Minh Thượng, tỉnh Kiên Giang.

\subsubsection{Thu thập số liệu so cấp}

Số liệu sơ cấp được thu thập từ phiếu phỏng vấn trực tiếp cán bộ nông nghiệp cấp xã về các vấn đề có liên quan đến hoạt động sản xuất nông nghiệp, hệ thống canh tác, tình hình xâm nhập mặn, biện pháp ứng phó của người dân, các trở ngại trong sản xuất...

Ngoài ra, số liệu được thu thập từ phiếu phỏng vấn trực tiếp 180 nông hộ tập trung vào lịch sử sử dụng đất đai, kỹ thuật canh tác, mức độ đầu tư, thu nhập và hiệu quả tài chính, khả năng thị trường. Ngoài ra, những thông tin được thu thập về xâm nhập mặn bao gồm thời gian xâm nhập mặn, giai đoạn nhiễm mặn trong năm, tác động của xâm nhập mặn, thuận lợi hoặc khó khăn trong sử dụng nước tưới, sự quan tâm của người dân về xâm nhập mặn trong tương lai, biện pháp thích ứng với xâm nhập mặn hiện tại của nông hộ.

Phương pháp được sử dụng để khảo sát và thu thập các thông tin về thực trạng các mô hình sản xuất là đánh giá nông thôn có sự tham gia của người dân (PRA) (Nguyễn Duy Cần \& Nico Vromant, 2009). Khảo sát PRA được thực hiện tại sáu địa điểm bao gồm xã Hòa Lợi, xã Bình Thạnh, thị trấn Thạnh Phú thuộc huyện Thạnh Phú, tỉnh Bến Tre và xã Vĩnh Hòa, xã Thạnh Yên, xã Minh Thuận thuộc huyện U Minh Thượng, tỉnh Kiên Giang.

\subsection{Phương pháp phân tích số liệu}

\subsubsection{Phương pháp thống kê mô tả}

Nghiên cứu sử dụng phần mềm Microsoft Excel để thống kê mô tả và trình bày số liệu về thông tin nông hộ được phỏng vấn bao gồm giá trị trung bình, giá trị nhỏ nhất, giá trị lớn nhất, tần số xuất hiện các đối tượng và sử dụng phần mềm SPSS phân tích phương sai (ANOVA) để so sánh khác biệt trung bình giữa các hệ thống canh tác.

\subsubsection{Phuơng pháp tính hiệu quả tài chính}

Hiệu quả tài chính của các hệ thống canh tác cây trồng được tính toán dựa vào các công thức sau:

Tổng chi phí (đồng/ha) = chi phí đầu vào + công lao động.

Tổng thu nhập (đồng/ha) = năng suất $(\mathrm{kg} / \mathrm{ha}) \mathrm{x}$ đơn giá (đồng $/ \mathrm{kg}$ ). phí.

Lợi nhuận (đồng/ha) = tổng thu nhập - tổng chi

Hiệu quả sử dụng đồng vốn $(\mathrm{B} / \mathrm{C})=$ tổng lợi nhuận/tổng chi phí. 
Trong đó:

Chi phí đầu vào (đồng/ha): gồm chi phí làm đất, giống, phân bón, thuốc bảo vệ thực vật, màng phủ nông nghiệp, bơm tưới.

Công lao động: gồm công gieo hạt, cấy dặm, bón phân, phun thuốc và thu hoạch.

\section{KẾT QUẢ VÀ THẢO LUẬN}

\section{1. Đặc điểm các hệ thống canh tác chủ yếu ở vùng nghiên cứu}

\subsubsection{Lịch thờ vu}

Kết quả khảo sát cho thấy lịch thời vụ trong vùng nghiên cứu thay đổi tùy loại cây trồng, thời tiết hàng năm ở từng địa phương và căn cứ vào kết quả quan trắc môi trường định kỳ của ngành chức năng. Nhằm hạn chế tác động của hạn, mặn ảnh hưởng đến cây trồng đặc biệt là cây lúa nên lịch thời vụ khuyến cáo của ngành nông nghiệp ở huyện Thạnh Phú, tỉnh Bến Tre như sau: đối với canh tác lúa 2 vư/năm thì vụ Hè Thu thường bắt đầu trễ, thời gian xuống giống phụ thuộc vào thời điểm có mưa, tập trung vào khoảng cuối tháng 5 dương lịch và thu hoạch vào giữa tháng 9 ; vụ Đông Xuân thường xuống giống từ cuối tháng 9 , thu hoạch khoảng đầu tháng 01 năm sau. Thời vụ rau màu được canh tác quanh năm từ tháng 01 đến tháng 12 . Đối với những vườn dừa mới

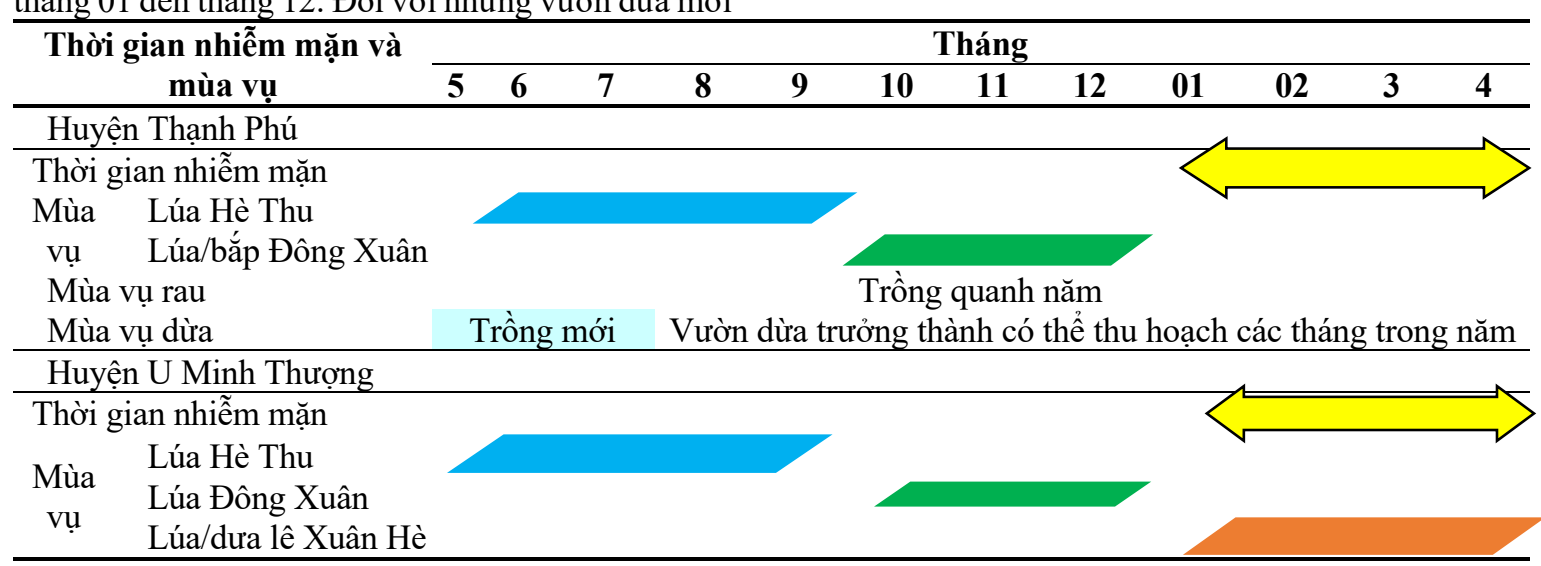

Hình 2. Lịch thời vụ canh tác tại huyện U Minh Thượng và huyện Thạnh Phú

Các hệ thống canh tác phổ biến

Huyện Thạnh Phú, Bến Tre có tổng diện tích gieo trồng lúa vụ Hè Thu năm 2020 với diện tích 174 ha, sản lượng thu hoạch hơn 530 tấn, vụ lúa mùa gieo trồng khoảng 4.000 ha. Diện tích lúa tập trung nhiều ở các xã vùng ngọt và một phần vùng lợ. Tuy nhiên, năng suất lúa bấp bênh do bị xâm nhập mặn nên diện tích gieo trồng lúa trên địa bàn các xã khu vực ngọt hóa giảm dần và tăng dần diện tích trồng dừa. Diện tích trồng dừa khoảng 7.540 ha, sản lượng chuyển đổi dừa, hộ dân thường bắt đầu trồng vào đầu mùa mưa từ tháng 5 đến tháng 7 và những vườn dừa có sẵn thì thu hoạch quanh năm, mỗi lần thu hoạch cách khoảng một tháng (Hình 2).

Do có điều kiện tự nhiên cùng bị ảnh hưởng của xâm nhập mặn hàng năm giống với huyện Thạnh Phú, tỉnh Bến Tre nên lịch thời vụ tại huyện U Minh Thượng, tỉnh Kiên Giang cũng được ngành nông nghiệp khuyến cáo chỉ nên canh tác lúa 2 vụ/năm, trong đó vụ Hè Thu từ giữa tháng 5 đến đầu tháng 9 dương lịch trùng với thời điểm mưa nhiều, thuận lợi cho việc sử dụng nước mưa để rửa mặn trong đất; vụ Đông Xuân bắt đầu từ giữa tháng 9 đến cuối tháng 12 dương lịch, giống lúa được khuyến cáo gieo sạ gồm các giống chịu mặn tốt và thời gian sinh trưởng ngắn ngày. Riêng đối với các hộ trồng lúa 3 vụ/năm và trồng dưa lê luân canh trên nền đất lúa 2 vụ thì ngay sau khi vừa thu hoạch vụ lúa Đông Xuân sẽ tiến hành làm đất, xuống giống lúa hoặc dưa lê giữa tháng 01 (Hình 2). Canh tác lúa, dưa lê vụ Xuân Hè trùng với thời gian nhiễm mặn nên nông dân đặc biệt gia cố đê bao để trữ ngọt trong kênh rạch phục vụ cho tưới tiêu, khi mặn xâm nhập sâu, nước trong các kênh rạch dần khô cạn thì việc tận dụng nước giếng khoan phục vụ tưới tiêu là giải pháp được người dân ưu tiên sử dụng. thu hoạch gần 60 triệu trái. Mặc dù bị ảnh hưởng bởi hạn mặn đầu năm 2020 nhưng đến nay vườn dừa trong huyện đã hồi phục và phát triển khá tốt. Theo Lâm Văn Tân và Lâm Thái Hùng (2021), diện tích chuyên canh lúa còn thích nghi với hệ thống 1 vụ lúa luân canh 1 vụ màu, trên thực tế thì diện tích luân canh lúa - màu tại huyện Thạnh Phú chưa phát triển nhiều mà tập trung hệ thống chuyên rau màu. Tổng diện tích trồng rau màu các loại khoảng 1.520 ha, sản lượng thu hoạch khoảng 49.500 tấn, được trồng nhiều trên đất giồng cát, trong thời gian gần đây, tại 
khu vực đất giồng cát nước ngầm bị cạn kiệt do khô hạn và xâm nhiễm mặn gây thiếu nước phục vụ tưới trong mùa khô nên hiệu quả chưa cao (Phòng Nông nghiệp và Phát triển nông thôn huyện Thạnh Phú, 2020).

Tại huyện U Minh Thượng, Kiên Giang, diện tích sản xuất lúa 2 vụ/năm là 13.636 ha, năng suất trung bình đạt 5,3 tấn/ha, sản lượng 72.271 tấn, trong đó lúa chất lượng cao chiếm $95 \%$, diện tích lúa 3 vụ/năm là 2.781,5 ha, năng suất trung bình đạt 5,01 tấn/ha, sản lượng 13.935 tấn. Đối với diện tích sản xuất lúa 3 vụ có 150 ha vụ Đông Xuân đã trổ đều và trong giai đoạn vào chắc, bị thiếu nước tưới và ảnh hưởng đến năng suất lúa do mặn xâm nhập sớm. Theo kết quả khảo sát của ngành chuyên môn và UBND xã có khoảng 60 ha bị thiệt hại trên $70 \%$, 90 ha bị thiệt hại từ 30-70\%. Bên cạnh hệ thống sản xuất lúa 3 vụ/năm, huyện U Minh Thượng cũng phát triển mạnh hệ thống luân canh lúa - màu với diện tích 465 ha, nhằm tăng giá trị sản xuất đối với diện tích 2 vụ lúa, góp phần cải tạo tăng độ phì nhiêu cho đất; ngành nông nghiệp huyện tăng cường công tác tuyên truyền vận động nông dân mạnh dạng luân canh cây màu trên đất trồng lúa, chuyển đổi cơ cấu cây trồng hợp lý; chọn những nơi có điều kiện thành lập các tổ hợp tác 2 vụ lúa - 1 vụ màu như: ấp Cạn ngọn, Xẻo Kè A, xã Thạnh Yên; ấp Xẻo Lùng, xã Thạnh Yên A; ấp Vĩnh Tiến, Vĩnh Thạnh xã Vĩnh Hòa; ấp Minh Cường, Minh Cường $\mathrm{A}$, Minh Tân $\mathrm{A}$, xã Minh Thuận. Trên cơ sở điều kiện của từng vùng và nhu cầu của thị trường, ngành chuyên môn xây dựng và triển khai dự án trồng màu trên đất lúa, đồng thời tranh thủ các chương trình, dự án của tỉnh về hỗ trợ cho nông dân trong việc luân canh cây màu trên đất lúa, chọn một số loại cây màu phù hợp với điều kiện đất đai thổ nhưỡng của từng vùng như: bắp, dưa lê, dưa hấu,... để triển khai thực hiện, trong đó dưa lê là cây màu đặc trưng của huyện (UBND huyện $\mathrm{U}$ Minh Thượng, 2021).

\subsubsection{Hiện trạng xâm nhập mặn}

Nghiên cứu hiện trạng xâm nhập mặn tại huyện Thạnh Phú cho thấy, các xã Bình Thạnh, Hòa Lợi và thị trấn Thạnh Phú là các xã thuộc tiểu vùng I của huyện đã được đầu tư thủy lợi ngăn mặn, là vùng ngọt hóa thuộc dự án 418 của Chính phủ, mỗi năm có từ 6 - 7 tháng nước ngọt, đủ bố trí sản xuất lúa 2 vụ/năm, 1 vụ lúa luân canh với 1 vụ màu hoặc chuyên canh màu. Tuy nhiên, vào mùa khô lưu lượng các sông Hàm Luông và Cổ Chiên bị cạn kiệt, bên ngoài đê bao độ mặn tăng cao, bên trong vùng ngọt hóa bị khô hạn dẫn đến thiếu nước nên tạo điều kiện đẩy nhanh tốc độ xâm nhập mặn, độ mặn có khi lên đến 4\%o ở những vùng ven tuyến đê bao ngọt hóa (UBND huyện Thạnh Phú, 2013). Kết quả khảo sát cho thấy thời gian nhiễm mặn tại khu vực nghiên cứu thường kéo dài từ $3-4$ tháng bắt đầu từ tháng 02 đến tháng 4 dương lịch ( $31 \%$ số phiếu điều tra), vào những năm thời tiết khô hạn kéo dài thì mặn xâm nhập sớm từ tháng 01 đến tháng 4 hoặc kéo dài đến khi có mưa (59\% số phiếu khảo sát).

Nghiên cứu hiện trạng xâm nhập mặn tại huyện U Minh Thượng cho thấy xã Thạnh Yên và xã Vĩnh Hòa là hai xã bị nhiễm mặn từ hệ thống sông Cái Lớn và một phần từ hệ thống kênh rạch của huyện An Biên. Vùng có độ mặn xâm nhập vào mùa khô khoảng 15 - 20\%o và thời gian nhiễm mặn khoảng 5 tháng, kéo dài từ cuối tháng 12 đến đầu tháng 5 dương lịch hàng năm. Xã Minh Thuận bị xâm nhập mặn từ tỉnh Cà Mau thông qua tuyến kênh Ranh Hạt và một phần từ tỉnh $\mathrm{Bạc}$ Liêu. Vùng này có độ mặn vào mùa khô tương đối cao (khoảng $20 \%$ ) và thời gian mặn kéo dài từ cuối tháng 12 đến khoảng giữa tháng 5 dương lịch hàng năm (UBND huyện U Minh Thượng, 2015). Kế quả khảo sát nông hộ cho thấy thời gian xâm nhập mặn bắt đầu từ đầu tháng 01 đến cuối tháng 4 (chiếm $54 \%$ tổng số phiếu điều tra), phân bố chủ yếu ở những khu vực dọc theo sông Cái Lớn; tuy nhiên vào những năm thời tiết khắc nghiệt như cuối năm 2019, đầu năm 2020 thời gian nhiễm mặn kéo dài trên 5 tháng bắt đầu từ đầu tháng 01 đến tháng 5 (chiếm $36 \%$ tổng số phiếu điều tra).

\subsection{Thông tin nông hộ tại vùng nghiên cứu}

Kết quả điều tra khảo sát Hình 3 cho thấy tại huyện Thạnh Phú đa số các hộ có số nhân khẩu từ 2 - 4 người chiếm tỷ lệ cao với $57 \%$ trên tổng số hộ điều tra, còn lại nhóm hộ có từ $5-8$ nhân khẩu chiếm tỷ lệ thấp hơn, với $43 \%$ trên tổng số hộ điều tra. Trong khi đó, tại huyện U Minh Thượng, đa số các hộ có số nhân khẩu từ $5-8$ người chiếm tỷ lệ cao hơn với $54 \%$ trên tổng số hộ điều tra và nhóm hộ có từ 2 - 4 nhân khẩu chiếm tỷ lệ thấp hơn, với $46 \%$ trên tổng số hộ điều tra.

Kết quả điều tra tại hai huyện cũng đã ghi nhận số người lao động chính của mỗi hộ bình quân 3 người/hộ. Những người lao động chính được hiểu là những người tạo ra thu nhập cho gia đình với nhiều công việc khác nhau, trong số này có người trực tiếp sản xuất nông nghiệp nhưng cũng có người đi làm thuê tại các nhà máy, xí nghiệp hoặc làm phụ hồ... Từ đó cho thấy số lao động trực tiếp sản xuất nông nghiệp ở khu vực này không nhiều nên chỉ có thể đáp ứng được hệ thống canh tác cần ít công lao động như canh tác nhỏ lẻ hoặc trồng lúa. Đối với hệ thống canh tác cần nhiều công lao động như trồng dưa lề 
ở huyện U Minh Thượng, các hộ phải thuê thêm công lao động bên ngoài. Vào lúc cao điểm nhiều hộ cùng xuống giống và thu hoạch đồng loạt sẽ dẫn đến khan hiếm nguồn lao động và chi phí thuê công lao động tăng lên.

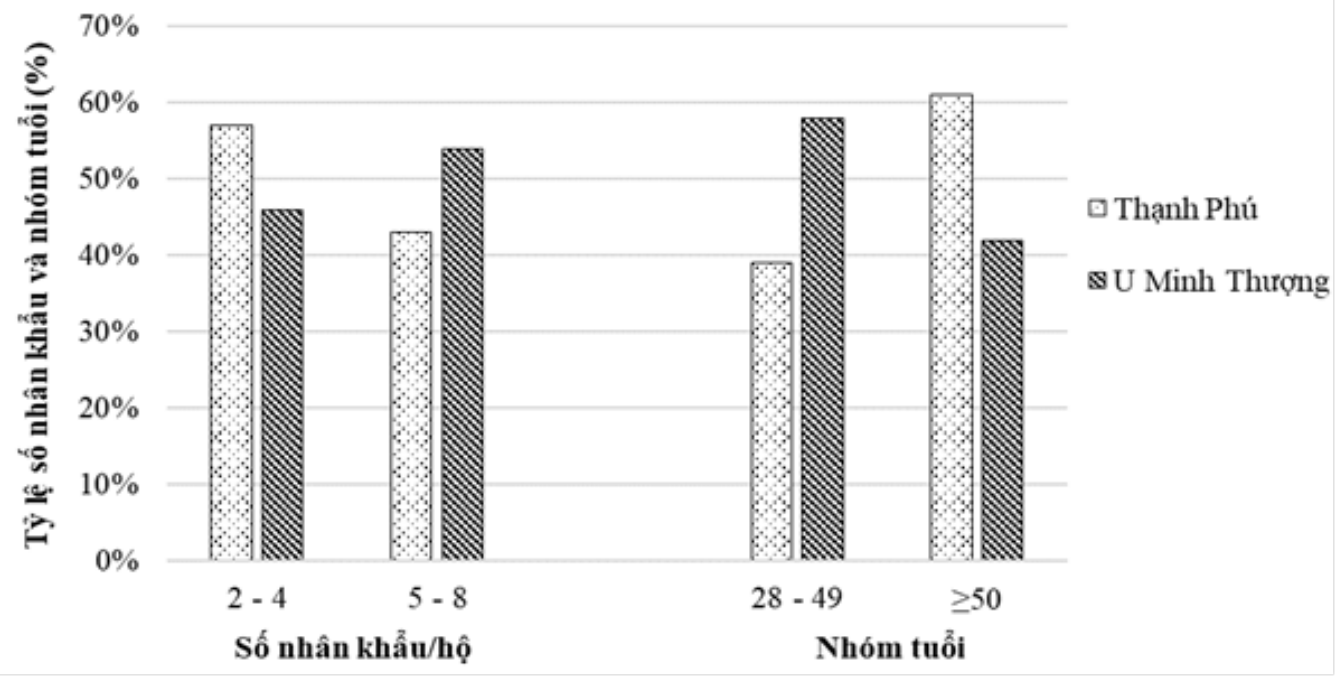

Hình 3. Số nhân khẩu trên hộ và độ tuổi chủ hộ tại huyện Thạnh Phú và huyện U Minh Thượng

Ngoài ra, kết quả Hình 3 cũng cho thấy đối tượng trực tiếp tham gia sản xuất nông nghiệp ở huyện Thạnh Phú tập trung chủ yếu ở nhóm hộ lớn tuổi từ 50 tuổi trở lên chiếm $61 \%$ so với tổng số phiếu điều tra, đối tượng trong nhóm tuổi từ 28 đến 49 tuổi chỉ chiếm $39 \%$. Nhóm cao tuổi có nhiều kinh nghiệm trong canh tác, tuy nhiên cũng sẽ gặp trở ngại về sức khỏe không đáp ứng với công việc cần nhiều sức lao động. Khác với huyện Thạnh Phú, tại huyện U Minh Thượng nhóm người trực tiếp tham gia sản xuất thuộc nhóm tuổi từ 28 đến 49 tuổi chiếm $58 \%$ cao hơn so với nhóm tuổi từ 50 tuổi trở lên với $42 \%$.

Bên cạnh sự thiếu hụt nguồn lực lao động ở nông thôn thì trình độ học vấn của người lao động cũng là trở ngại lớn trong việc phát triển sản xuất ở địa phương. Theo kết quả khảo sát ở Bảng 2 cho thấy, trình độ học vấn của chủ hộ tập trung chủ yếu vào cấp I và cấp II ở cả hai huyện. Tại huyện Thạnh Phú, nhóm chủ hộ có trình độ cấp I có tỷ lệ cao nhất chiếm $47 \%$, kế đến là nhóm chủ hộ có trình độ cấp II chiếm $43 \%$, nhóm trình độ học vấn cấp III chiếm tỷ lệ thấp nhất $10 \%$. Tương tự, tại huyện U Minh Thượng, chủ hộ có trình độ học vấn cấp I chiếm tỷ lệ cao nhất $44 \%$ và cấp II chiếm $38 \%$ và trình độ cấp III chiếm tỷ lệ thấp nhất với $18 \%$. Theo Vũ Văn Hùng và Hồ Kìm Hương (2020), học vấn của chủ hộ có tác động tích cực đến hiệu quả sản xuất, canh tác của nông hộ, nếu chủ hộ tăng thêm một năm học phổ thông, điểm hiệu quả sản xuất của nông hộ có thể tăng thêm khoảng 19\%. Do đó, tỷ lệ nông hộ có trình độ học vấn cấp I và cấp II chiếm $90 \%$ có thể là yếu tố ảnh hưởng đến hiệu quả sản xuất của nông hộ.

Bảng 2. Trình độ học vấn của chủ hộ tại khu vực nghiên cứu

\begin{tabular}{lrrrr}
\hline \multirow{2}{*}{ Trình độ học vấn chủ hộ } & \multicolumn{2}{c}{ Huyện Thạnh Phú } & \multicolumn{2}{c}{ Huyện U Minh Thượng } \\
\cline { 2 - 5 } & Số hộ & Tỷ lệ (\%) & Số hộ & Tỷ lệ (\%) \\
\hline Cấp I & 42 & 47 & 40 & 44 \\
Cấp II & 39 & 43 & 34 & 38 \\
Cấp III & 9 & 10 & 16 & 18 \\
\hline Tống & 90 & 100 & 90 & 100 \\
\hline
\end{tabular}

Kết quả khảo sát cũng cho thấy diện tích đất canh tác của nông hộ còn manh mún, không tập trung cũng gây khó khăn trong việc điều tiết nước, quản lý dịch hại và hạn chế trong việc áp dụng cơ giới hóa vào sản xuất nên hiệu quả sản xuất chưa cao. Tại huyện Thạnh Phú, diện tích đất sản xuất trung bình là 0,66 ha/hộ và tại huyện $U$ Minh Thượng là 1,02 ha/hộ. Để khắc phục vấn đề trên, người dân cần tuân thủ sản xuất theo quy hoạch của ngành nông nghiệp, ứng dụng tiến bộ khoa học kỹ thuật vào sản xuất để tăng năng suất và nâng cao giá trị nông sản. 


\subsection{Các trở ngại và sự thích ứng của nông hộ với xâm nhập mặn}

\subsubsection{Các trở ngại đối với sản xuất nông hộ}

Xâm nhập mặn đã và đang tác động đến đời sống và sản xuất của người dân trên địa bàn nghiên cứu. Kết quả điều tra các trở ngại chính trong sản xuất tại huyện Thạnh Phú Hình 4 cho thấy xâm nhập mặn là yếu tố trở ngại lớn nhất (chiếm $46 \%$ tổng số phiếu điều tra), yếu tố trở ngại thứ 2 là phèn và mặn $(31 \%)$ và các bất lợi khác (23\%) bao gồm dịch hại, thời tiết, kỹ thuật canh tác.

Huyện U Minh Thượng, tỉnh Kiên Giang ghi nhận sự kết hợp của phèn và mặn là yếu tố trở ngại lớn nhất (chiếm $40 \%$ tổng số phiếu điều tra), tiếp đến là xâm nhập mặn $(32 \%)$ và các bất lợi khác (28\%) bao gồm dịch hại, thời tiết, kỹ thuật canh tác (Hình 4). Điều này cho thấy ảnh hưởng do phèn mặn là hai bất lợi chính trong quá trình sản xuất và canh tác của người dân trong khu vực khảo sát.

Để khắc phục các trở ngại trên, việc áp dụng các biện pháp kỹ thuật vào sản xuất như: gieo sạ theo lịch thời vụ khuyến cáo của ngành nông nghiệp, thay đổi cơ cấu mùa vụ, chọn giống cây trồng chịu phèn, mặn, làm đất đúng kỹ thuật, thay đổi tập quán canh tác chỉ bón phân vô cơ, tăng cường bón phân hữu cơ cải tạo đất theo khuyến cáo của các nhà khoa học.
Trở ngại do xâm nhập mặn

Trở ngai do ành hưởng phèn mặn

Trờ ngại khác



Trước sự thay đổi cực đoan của thời tiết, việc dự báo mức độ nhiễm mặn hàng năm là yếu tố quan trọng để nông hộ chuẩn bị kế hoạch sản xuất và ứng phó kịp thời với tác động của biến đổi khí hậu. Kết quả điều tra về dự đoán mức độ xâm nhập mặn trong tương lai tại huyện Thạnh Phú với $64 \%$ phiếu điều tra dự đoán mức độ xâm nhập mặn của năm sau cao hơn so với năm trước, dự đoán này phù hợp với kết quả khảo sát hiện trạng xâm nhập mặn vào kênh nội đồng và đất nông nghiệp tại huyện Long Mỹ - tỉnh Hậu Giang của Lê Hồng Việt và ctv. (2015) cho thấy hiện trạng xâm nhập mặn nguồn nước kênh trong năm sau (2013) cao hơn so với năm trước (2012). Ngoài ra, số hộ dự đoán mức độ xâm nhập mặn không thay đổi chiếm $18 \%$ và chỉ có $10 \%$ số hộ dự đoán mức độ xâm nhập mặn thấp hơn, số còn lại là số hộ không đưa ra dự đoán chiếm $8 \%$ (Hình 5).

Tương tự, huyện U Minh Thượng có 58\% phiếu điều tra dự đoán mức độ xâm nhập mặn của năm sau cao hơn năm trước, $18 \%$ dự đoán không thay đổi và chỉ có $13 \%$ dự đoán thấp hơn, số còn lại không dự đoán chiếm $11 \%$ do người dân không đủ thông tin và kiến thức để đưa ra nhận định của cá nhân (Hình 5). 


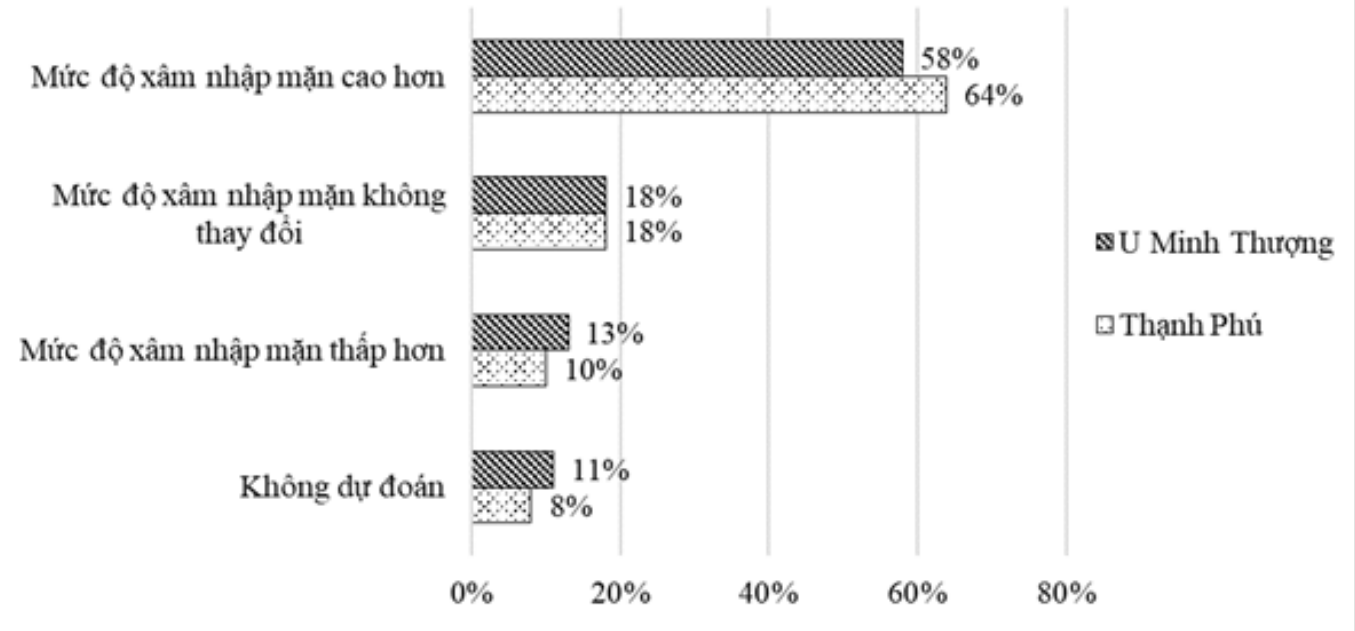

\section{Hình 5. Tỷ lệ \% hộ dự đoán mức độ xâm nhập mặn trong tương lai tại khu vực nghiên cứu}

Trước tác động của biến đổi khí hậu cụ thể là xâm nhập mặn, người dân đã nhận thấy những rủi ro tiềm ẩn và gây bất lợi đến hoạt động sản xuất hiện tại nên việc thay đổi hệ thống canh tác trong tương lai là cần thiết. Kết quả khảo sát tại Bảng 3 cho thấy huyện Thạnh Phú có $25 \%$ số nông hộ muốn thay đồi hệ thống canh tác. Tuy nhiên, số hộ không muốn thay đổi hệ thống canh tác lại chiếm tỷ cao nhất với $75 \%$ tổng số phiếu điều tra. Tương tự, tại huyện $\mathrm{U}$ Minh Thượng có 33\% người dân trong khu vực nghiên cứu muốn thay đổi hệ thống canh tác để phù hợp với điều kiện xâm nhập mặn trong tương lai và $67 \%$ nông hộ không muốn thay đổi hệ thống canh tác hiện tại. Mặc dù, đa số nông hộ nhận định mức độ xâm nhập mặn ngày càng gia tăng trong tương lai nhưng việc quyết định thay đổi hệ thống canh tác đối với người dân sẽ gặp nhiều khó khăn do thiếu thông tin, thiếu công lao động, chưa am hiểu các kỹ thuật canh tác mới nên chưa mạnh dạn thay đổi để thích ứng với tình hình xâm nhập mặn trong tương lai.

\section{Bảng 3. Khảo sát nông hộ về nhu cầu thay đổi hệ thống canh tác tại khu vực nghiên cứu}

\begin{tabular}{lrr}
\hline Huyện & $\begin{array}{r}\text { Muốn thay Không muốn thay } \\
\text { dổi }\end{array}$ \\
\hline Thạnh Phú & $25 \%$ & $75 \%$ \\
U Minh Thượng & $33 \%$ & $67 \%$ \\
\hline
\end{tabular}

\subsection{Hiệu quả tài chính của các hệ thống canh tác chính tại khu vực nghiên cứu}

3.4.1. Hiệu quả tài chính của các hệ thống canh tác chính tại huyện Thạnh Phú, tỉnh Bến Tre

Kết quả điều tra ở Bảng 4 cho thấy tổng chi phí của hệ thống lúa 2 vụ/năm là 33,79 triệu đồng/ha/năm, tổng thu nhập đạt 56,34 triệu đồng/ha/năm và hiệu quả sử dụng đồng vốn là 0,67 . Trong khi đó, tổng chi phí của hệ thống canh tác lúa - bắp là 41,31 triệu đồng/ha/năm cao hơn hệ thống lúa 2 vụ/năm 7,52 triệu đồng, tuy nhiên tổng thu nhập đạt 72,93 triệu đồng/ha/năm nên lợi nhuận của hệ thống này cao hơn hệ thống lúa 2 vụ/năm là 16,59 triệu đồng và hiệu quả sử dụng đồng vốn là 0,77 cao hơn hệ thống lúa 2 vụ/năm $(0,67)$. Trong hệ thống canh tác luân canh lúa - bắp, năng suất lúa vụ Hè Thu đạt 4,21 tấn/ha/vụ cao hơn so với năng suất lúa vụ Hè Thu trong hệ thống lúa 2 vụ (4,06 tấn/ha/vụ). Nguyên nhân có thể là do trong quá trình trồng bắp, nông dân có bón thêm phân bò phơi khô nên hàm lượng dinh dưỡng trong phân bò đã cải thiện độ phì nhiêu đất ở vụ lúa tiếp theo. Điều kiện đất thoáng khí khi canh tác vụ bắp cũng đã cải thiện hoạt động của vi sinh vật đất, tăng cường phân giải chất hữu cơ và khoáng hóa các nguyên tố từ các thành phần hữu cơ góp phần gia tăng năng suất lúa. Kết quả này phù hợp với nghiên cứu của Võ Thị Gương và ctv. (2010), luân canh lúa với cây trồng cạn, có sử dụng phân hữu cơ, góp phần cải thiện độ phì nhiêu đất về mặt hóa, lý và sinh học, do đó tăng năng suất lúa canh tác ở vụ sau. Trước tình hình vùng canh tác bị ảnh hưởng của xâm nhập mặn và khô hạn cần đa dạng hóa hệ thống cây trồng và áp dụng các biện pháp kỹ thuật như bón phân hữu cơ là cần thiết để cải thiện hiệu quả tài chính so với canh tác truyền thống. Đề xuất này phù hợp với nghiên cứu của Lâm Văn Tân và ctv. (2014), ở tiểu vùng có đê bao cần đưa vào thực tế sản xuất một số mô hình đạt hiệu quả kinh tế cao như mô hình lúa - bắp nhằm đa dạng hóa cho vùng chỉ độc canh cây lúa. Do đó, việc chuyển đổi hệ thống canh tác lúa 2 vụ/năm kém hiệu 
quả sang hệ thống luân canh lúa - màu (bắp) phù hợp với chuyển đổi sản xuất nông nghiệp của địa phương. Tuy nhiên, nếu diện tích canh tác màu tăng lên cần gắn kết với doanh nghiệp tiêu thụ để đảm bảo đầu ra cho người sản xuất.

Tại xã Hòa Lợi, nông dân có xu hướng chuyển từ diện tích đất canh tác lúa kém hiệu quả sang trồng dừa. Nông dân ở khu vực này thường trồng dừa truyền thống, giống dừa thân cao và bán trái dừa khô. Tổng chi phí của hệ thống chuyên canh dừa là 18,27 triệu đồng/ha/năm và tổng thu nhập đạt 62,79 triệu đồng/ha/năm. Do chi phí đầu tư thấp nên hiệu quả sử dụng đồng vốn của hệ thống canh tác này khá cao $(2,44)$. Đối với hệ thống chuyên canh dừa, nông dân ít tốn công chăm sóc. Kết quả Bảng 4 cho thấy hệ thống chuyên dừa có công lao động thấp nhất nên hệ thống này phù hợp với nông hộ không chủ động được công lao động. Ngoài ra, để nâng cao hiệu quả tài chính nông hộ cần kết hợp nuôi thủy sản trong mương dừa. Đề xuất này phù hợp với nghiên cứu của Lâm Văn Tân và ctv. (2014), ở tiểu vùng ngọt cần đưa vào thực tế sản xuất một số mô hình đạt hiệu quả kinh tế cao như nuôi tồm càng xanh trong mương dừa nhằm đa dạng hóa cho vùng chỉ độc canh cây lúa hay chuyên canh dừa.

Xã Bình Thạnh phát triển hệ thống chuyên canh rau trên đất giồng cát. Tổng chi phí của hệ thống chuyên canh rau là 43,43 triệu đồng/ha/năm, tổng thu nhập đạt 160,07 triệu đồng/ha/năm. Đây là hệ thống canh tác cho lợi nhuận cao nhất trong các hệ thống canh tác chính tại huyện Thạnh Phú, tỉnh Bến Tre, với lợi nhuận đạt 116,64 triệu đồng/ha/năm và hiệu quả sử dụng đồng vốn là 2,69 . Tuy nhiên, đối với hệ thống chuyên canh rau, các hộ nông dân chỉ canh tác với quy mô nhỏ, diện tích từ $500-3.000$ $\mathrm{m}^{2} /$ hộ; hệ thống này cần nhiều công chăm sóc và canh tác liên tục nhiều vụ trong năm, khoảng 7 - 8 vụ/năm. Kết quả Bảng 4 cho thấy công lao động của hệ thống chuyên canh rau chiếm $47,5 \%$ so với tổng chi phí. Do đó, hệ thống canh tác này phù hợp với những nông hộ chủ động được công lao động tại chỗ và làm việc liên tục.

\section{Bảng 4. Hiệu quả tài chính của các hệ thống canh tác chính tại huyện Thạnh Phú, tỉnh Bến Tre}

ĐVT: triệu đồng/ha/năm

\begin{tabular}{lrrrrr}
\hline \multirow{2}{*}{ Hạng mục } & \multicolumn{3}{c}{ Hệ thống canh tác } & \multicolumn{2}{c}{ Giá trị } \\
\cline { 2 - 5 } & Chuyên rau & Chuyên dừa & Lúa 2 vụ & Lúa - Bắp & F \\
\hline Chi phí đầu vào & 22,80 & 11,84 & 24,19 & 27,39 & \\
Công lao động & 20,63 & 6,43 & 9,59 & 13,91 & \\
Tổng chi phí & $43,43 \pm 1,11^{\mathrm{a}}$ & $18,27 \pm 0,66^{\mathrm{d}}$ & $33,79 \pm 0,77^{\mathrm{c}}$ & $41,31 \pm 0,92^{\mathrm{b}}$ & $* * *$ \\
Năng suất $(\mathrm{kg} / \mathrm{ha}$; trái/ha (dì̀a)) & $21.126 \pm 574$ & $10.353 \pm 482$ & $8.114 \pm 430$ & $11.028 \pm 276$ & \\
Giá bán (đồng/kg; đồng/trái (dìa $)$ ) & 7.577 & 6.065 & 6.943 & 6.613 & \\
Tổng thu nhập & $160,07 \pm 1,44^{\mathrm{a}}$ & $62,79 \pm 0,85^{\mathrm{c}}$ & $56,34 \pm 0.96^{\mathrm{d}}$ & $72,93 \pm 1,18^{\mathrm{b}}$ & $* * *$ \\
Lợi nhuận & $116,64 \pm 1,43^{\mathrm{a}}$ & $44,52 \pm 1,13^{\mathrm{b}}$ & $22,55 \pm 0,84^{\mathrm{d}}$ & $31,62 \pm 0,98^{\mathrm{c}}$ & $* * *$ \\
Hiệu quả sử dụng đồng vốn $(\mathrm{B} / \mathrm{C})$ & $2,69 \pm 0,02^{\mathrm{a}}$ & $2,44 \pm 0,02^{\mathrm{b}}$ & $0,67 \pm 0,02^{\mathrm{d}}$ & $0,77 \pm 0,02^{\mathrm{c}}$ & $* * *$ \\
\hline
\end{tabular}

Ghi chú: Trên cùng một hàng, giá trị trung bình theo sau các mẫu tụ khác nhau $(a, b, c, d)$ thì khác biệt có ý nghĩa ở múc ý nghĩa $p<0,001$ qua phép thử Duncan. Nguồn: Số liệu điều tra thực tế năm 2020; $(n=90)$

\subsubsection{Hiệu quả tài chính của các hệ thống canh tác chính tại huyện U Minh Thuợng, tỉnh Kiên Giang}

Hiệu quả tài chính ở Bảng 5 cho thấy tổng chi phí của hệ thống lúa 3 vụ/năm là 48,81 triệu đồng/ha/năm, tổng thu nhập đạt 75,95 triệu đồng/ha/năm và hiệu quả sử dụng đồng vốn 0,56 . Tuy nhiên, do điều kiện canh tác không thuận lợi nên năng suất lúa vụ Xuân Hè thấp hơn vụ Hè Thu và Đông Xuân. Theo kết quả điều tra, năng suất lúa vụ Xuân Hè chỉ đạt trung bình 3,96 tấn/ha, thấp hơn đáng kể so với năng suất lúa vụ Hè Thu 5,32 tấn/ha và vụ Đông Xuân 6,30 tấn/ha nên năng suất trung bình của 3 vụ chỉ đạt 5,19 tấn/ha/vụ. Ngành nông nghiệp địa phương khuyến cáo người dân không canh tác lúa vụ Xuân Hè vì thời điểm này nguồn nước bị nhiễm mặn trong khi cây lúa cần nhiều nước để sinh trưởng và phát triển.

Do điều kiện tự nhiên bị nhiễm mặn từ tháng 01 đến tháng 05 hàng năm nên tại các xã khảo sát chỉ thuận lợi cho canh tác lúa 2 vụ/năm. Kết quả Bảng 5 cho thấy tổng chi phí canh tác lúa 2 vụ là 34,06 triệu đồng/ha/năm, năng suất lúa trung bình đạt 5,94 tấn/ha/vụ, tổng thu nhập 60,12 triệu đồng/ha/năm, hiệu quả sử dụng đồng vốn 0,76 . Nếu tính tổng thu nhập trong năm thì hệ thống canh tác lúa 2 vụ thấp hơn canh tác lúa 3 vụ, tuy nhiên lợi nhuận bình quân từng vụ thì canh tác lúa 2 vụ có lợi nhuận $(13,03$ 
triệu đồng/ha/vụ) cao hơn lợi nhuận trung bình của canh tác lúa 3 vụ (9,05 triệu đồng/ha/vụ) và hiệu quả sử dụng đồng vốn hệ thống lúa 2 vụ lúa $(0,76)$ cao hơn hệ thống lúa 3 vụ $(0,56)$. Nguyên nhân do vụ điều kiện canh tác vụ Xuân Hè có nhiều bất lợi, tăng chi phí sản xuất nhưng giảm năng suất và lợi nhuận nên hiệu quả sử dụng đồng vốn của hệ thống lúa 3 vụ thấp hơn hệ thống lúa 2 vụ. Ngoài ra, canh tác lúa 2 vụ có chi phí công lao động thấp nhất nên phù hợp với khu vực khan hiếm công lao động.

So với hệ thống canh tác lúa 3 vụ/năm thì hệ thống luân canh dưa lê trên nền đất lúa 2 vụ được ngành nông nghiệp khuyến cáo và phù hợp với định hướng tái cơ cấu ngành nông nghiệp của huyện vì trồng dưa lê vụ Xuân Hè tiêu tốn ít nước hơn trồng lúa. Tổng chi phí của hệ thống lúa 2 vụ - dưa lê là 93,54 triệu đồng/ha/năm và tổng thu nhập đạt 145,38 triệu đồng/ha/năm. Đây là hệ thống canh tác cho lợi nhuận cao nhất trong các hệ thống canh tác chính tại các xã khảo sát, với lợi nhuận đạt 51,84 triệu đồng/ha/năm, năng suất lúa trung bình đạt 5,91 tấn/ha/vụ cao hơn năng suất trung bình của hệ thống lúa 3 vụ $(5,19$ tấn/ha/vụ), trong đó năng suất lúa vụ Hè Thu đạt 5,45 tấn/ha tương đương với năng suất Hè Thu của hệ thống lúa 2 vụ/năm và cao hơn năng suất vụ Hè Thu của hệ thống lúa 3 vụ/năm $(5,28$ tấn/ha). Tương tự, năng suất lúa vụ Đông Xuân của hệ thống lúa 2 vụ - dưa lê là 6,41 (tấn/ha) tương đương với năng suất lúa vụ Đông Xuân của hệ thống lúa 2 vụ/năm (6,43 tấn/ha) và cao hơn năng suất vụ
Đông Xuân của hệ thống lúa 3 vụ/năm (6,34 tấn/ha). Như vậy, việc luân canh lúa 2 vụ với dưa lê góp phần gia tăng năng suất lúa ở các vụ canh tác so với canh tác lúa 3 vụ/năm. Theo Võ Thị Gương và ctv. (2010), luân canh lúa với cây trồng cạn tạo thời gian đất được phơi khô và phân huỷ các chất hữu cơ trong đất cũng như tạo được môi trường cho những vi sinh vật háo khí hoạt động và đa dạng hoá các hệ động vật khác trong đất giúp tăng khả năng cung cấp dinh dưỡng từ đất và tăng năng suất lúa. Tuy nhiên, do chi phí đầu tư cho dưa lê khá cao nên hiệu quả sử dụng đồng vốn là 0,55 thấp hơn canh tác lúa $2-3$ vụ/năm. Đối với hệ thống canh tác này, việc sử dụng nước ngầm phục vụ sản xuất ở những vùng đang bị ảnh hưởng của xâm nhập mặn về lâu dài có thể tiềm ẩn nhiều nguy cơ như cạn kiệt nguồn nước, mạch nước ngầm bị ô nhiễm hoặc nhiễm mặn. Do đó, việc canh tác các đối tượng cây màu vào mùa khô, các hộ dân cần lưu ý việc khai thác, sử dụng tiết kiệm nguồn nước ngầm và sản xuất theo quy hoạch vùng trồng của chính quyền địa phương. Ngoài ra, để hệ thống canh tác này đạt hiệu quả cao và bền vững, nông dân cần lưu ý áp dụng đúng kỹ thuật canh tác, tăng cường bón phân hữu cơ ở vụ màu để cải thiện độ phì nhiêu đất và năng suất lúa ở vụ sau (Võ Thị Gương và ctv., 2010) và gắn kết với doanh nghiệp để thúc đẩy liên kết tiêu thụ. Ngoài ra, hệ thống luân canh lúa 2 vụ - dưa lê cần nhiều công lao động, qua kết quả Bảng 5 cho thấy công lao động chiếm 34,5\% so với tổng chi phí, có thể giải quyết được công lao động nhàn rỗi ở địa phương.

Bảng 5. Hiệu quả kinh tế của các hệ thống canh tác chính tại huyện U Minh Thượng, tỉnh Kiên Giang ĐVT: triệu đồng/ha/năm

\begin{tabular}{lrrrr}
\hline \multirow{2}{*}{ Hạng mục } & \multicolumn{3}{c}{ Hệ thống canh tác } & Giá trị F \\
\cline { 2 - 5 } & Lúa 3 vụ & Lúa 2 vụ & Lúa 2 vụ - dưa lề \\
\hline Chi phí đầu vào & 36,94 & 25,98 & 61,27 & \\
Công lao động & 11,87 & 8,08 & 32,27 & \\
Tổng chi phí & $48,81 \pm 0,78^{\mathrm{b}}$ & $34,06 \pm 0,65^{\mathrm{c}}$ & $93,54 \pm 0,89^{\mathrm{a}}$ & $* * *$ \\
Năng suất $(\mathrm{kg} / \mathrm{ha})$ & $15.579 \pm 446$ & $11.870 \pm 489$ & $28.191 \pm 559$ & \\
Giá bán $($ đồng/ $/ \mathrm{kg})$ & 4.875 & 5.064 & 5.157 & \\
Tổng thu nhập & $75,95 \pm 0,94^{\mathrm{b}}$ & $60,12 \pm 0,82^{\mathrm{c}}$ & $145,38 \pm 1,28^{\mathrm{a}}$ & $* * *$ \\
Lợi nhuận & $27,14 \pm 1,07^{\mathrm{b}}$ & $26,05 \pm 0,89^{\mathrm{c}}$ & $51,84 \pm 1,34^{\mathrm{a}}$ & $* * *$ \\
Hiệu quả sử dụng đồng vốn $(\mathrm{B} / \mathrm{C})$ & $0,56 \pm 0,01^{\mathrm{b}}$ & $0,76 \pm 0,02^{\mathrm{a}}$ & $0,55 \pm 0,01^{\mathrm{c}}$ & $* * *$ \\
\hline
\end{tabular}

Ghi chú: Trên cùng một hàng, giá trị trung bình theo sau các mãu tụ khác nhau $(a, b, c)$ thì khác biệt có ý nghĩa ở mức ý nghĩa $p<0.001$ qua phép thử Duncan. Nguồn: Số liệu điều tra thực tế năm $2020(n=90)$.

\section{KẾT LUẬN VÀ KIẾN NGH!}

Hiện trạng canh tác tại khu vực nghiên cứu còn nhiều khó khăn, xâm nhập mặn và ảnh hưởng phèn mặn là hai trở ngại chính ảnh hưởng đến hệ thống canh tác và mức độ xâm nhập mặn được nông hộ dự đoán ngày càng gia tăng, huyện Thạnh Phú chiếm $64 \%$ và huyện U Minh Thượng chiếm $58 \%$.

Tại huyện Thạnh Phú, tỉnh Bến Tre, hệ thống chuyển canh rau cho lợi nhuận cao nhất, kế đến là hệ thống chuyên canh dừa, hệ thống canh tác lúa 2 vụ/năm cho lợi nhuận thấp nhất. Tương tự, hiệu quả 
sử dụng đồng vốn của hệ thống chuyên canh rau cao nhất, kế đến là hệ thống chuyên canh dừa, tiếp theo là hệ thống luân canh lúa - bắp và thấp nhất là hệ thống lúa 2 vư/năm. Trong hệ thống luân canh lúa bắp, năng suất lúa vụ Hè Thu cao hơn so với năng suất lúa cùng vụ của hệ thống lúa 2 vụ/năm.

Tại huyện U Minh Thượng, tỉnh Kiên Giang, hệ thống luân canh lúa 2 vụ - dưa lê cho lợi nhuận cao nhất, kế đến là hệ thống lúa 3 vụ/năm và thấp nhất là hệ thống lúa 2 vụ/năm. Ngoài ra, năng suất lúa vụ Hè Thu và Đông Xuân trong hệ thống luân canh lúa 2 vụ - dưa lê gia tăng so với năng suất lúa cùng vụ của hệ thống lúa 3 vụ/năm. Tuy nhiên, xét về hiệu quả sử dụng đồng vốn thì hệ thống lúa 2 vụ/năm cao nhất, kế đến là hệ thống lúa 3 vụ/năm và thấp nhất là hệ thống luân canh lúa 2 vụ - dưa lê.

Trước tác động tiêu cực của biến đổi khí hậu, những nghiên cứu sâu hơn về diễn biến xâm nhập mặn và các hệ thống canh tác chuyển đổi qua nhiều năm là cần thiết để xác định khả năng thích nghi của các hệ thống canh tác với điều kiện xâm nhập mặn tại huyện Thạnh Phú và huyện U Minh Thượng theo thời gian.

\section{LỜI CẢM TẠ}

Đề tài được thực hiện với sự hỗ trợ và tạo điều kiện thuận lợi của Phòng Nông nghiệp và Phát triển nông thôn huyện Thạnh Phú, tỉnh Bến Tre, Phòng Nông nghiệp và Phát triển nông thôn huyện U Minh Thượng, tỉnh Kiên Giang trong quá trình điều tra, thu thập số liệu tại địa phương. Nhóm tác giả xin cảm ơn chương trình nghiên cứu A-8 thuộc Dự án ODA-Nhật Bản đã hỗ trợ một phần cho nghiên cứu này.

\section{TÀI LIỆU THAM KHẢO}

Cục Thống kê tỉnh Bến Tre. (2020). Báo cáo tình hình kinh tế - xã hội tỉnh Bến Tre tháng 02 và 2 tháng năm 2020.

Cục Trồng trọt. (2016). Đánh giá tác động của biến đổi khi hậu và xâm nhập mặn năm 2015 - 2016.

Duong, V. H. T. (2018). Land used based flood hazard analysis for the Mekong Delta. [Doctoral Dissertation, Karlsruhe Institute of Technology, Karlsruhe, Germany]. http://doi.org/10.5445/IR/1000089862

Lâm Văn Tân \& Lâm Thái Hùng. (2021). Xây dựng bản đồ đánh giá sư thích nghi của cây trồng đối với đặc tính môi trưòng đất đai của huyện Thạnh Phú. https://tapchicongthuong.vn/bai-viet/xaydung-ban-do-danh-gia-su-thich-nghi-cua-caytrong-doi-voi-dac-tinh-moi-truong-dat-dai-cuahuyen-thanh-phu-tinh-ben-tre-79848.htm

Lâm Văn Tân, Võ Thị Gương, Dương Nhựt Long \& Nguyễn Hồng Giang. (2014). Hiệu quả kinh tế các mô hình canh tác phù hợp trên đất ven biển huyện Thạnh Phú, tỉnh Bến Tre. Tạp chí Khoa học Đại học Cần Tho. Nông nghiệp, Thủy sản và Công nghệ Sinh học, 32(2), 76-82.

Lê Hồng Việt, Châu Minh Khôi \& Đỗ Bá Tân. (2015). Khảo sát hiện trạng xâm nhập mặn nước và đất nông nghiệp tại huyện Long Mỹ, tỉnh Hậu Giang. Tap chi Khoa hoc Đai học Cần Tho; 38(2), 48-54.

Nguyễn Duy Cần \& Nico Vromant. (2009). PRA Đánh giá nông thôn với sư tham gia của người dân. NXB Nông nghiệp thành phố Hồ Chí Minh.

Phòng Nông nghiệp và Phát triển nông thôn huyện Thạnh Phú. (2020). Báo cáo kết quả thưc hiện đề án tái cơ cấu ngành nông nghiẹp theo huớng nâng cao giá trị gia tăng và phát triền bền vũng, phù hợ với từng vùng sinh thái tại huyện Thạnh Phú.

Phòng Nông nghiệp và Phát triển nông thôn huyện $\mathrm{U}$ Minh Thượng. (2020). Báo cáo tình hình gieo sa và thiệt hại lúa Hè Thu năm 2020 do hạn, mạn và dịch bệnh.

Thanh, N. C. (2016). Saltwater intrusion - An evident impact of climate change in the MD and propose adaptable solutions. American Journal of Environmental and Resource Economics, 1(1), 1-8.

Ủy ban Nhân dân huyện Thạnh Phú. (2013). Báo cáo tình hình xâm nhập mặn ảnh huơong đến cây trồng vật nuôi huyện Thạnh Phú năm 2013.

Ủy ban Nhân dân huyện U Minh Thượng. (2015). Kế hoạch tái co cấu các tiểu vùng sản xuất nông nghiệp giai đoạn 2016-2020.

Ủy ban Nhân dân huyện U Minh Thượng. (2020). Báo cáo tổng kết tình hình thực hiện nhiệm vu sản xuất năm 2020 và kế hoạch sản xuất năm 2021.

Võ Thị Gương, Dương Minh Viễn, Nguyễn Minh Đông \& Huỳnh Đào Nguyên. (2010). Cải thiện độ phì nhiêu đất và năng suất lúa canh tác ba vu trong đê bao tại Đồng bằng sông Cưu Long. Nhà xuất bản Nông nghiệp - TP Hồ Chí Minh.

Vũ Văn Hùng \& Hồ Kim Hương. (2020). Vai trò của học vấn đối với hiệu quả sản xuất chè của nông hộ vùng Bắc Trung Bộ Việt Nam. Tạp chí Khoa học Thuong mai, 139, 47-54. 